\title{
FANTASY WORD SOUNDING IN MARKETING PHONOSEMANTICS
}

\author{
Maria Danilchuk
}

\section{The Herzen State Pedagogical University of Russia, Saint Petersburg, Russia}

\begin{abstract}
Danilchuk, M. (2018). Fantasy word sounding in marketing phonosemantics. In Lege artis. Language yesterday, today, tomorrow. The journal of University of SS Cyril and Methodius in Trnava. Warsaw: De Gruyter Poland, 2018, III (2), December 2018, p. 1-37. DOI: 10.2478/lart-2018-0013 ISSN 24538035
\end{abstract}

\begin{abstract}
The paper represents the results of a linguistic experiment aimed at establishing if the sounding of different fantasy brand names can cause the same associations in collective consciousness. The experiment drew upon crowdsourcing. The data received can be useful for marketing phonosemantics in relation to the methods used for the creation of new brand names.
\end{abstract}

Key words: phonosemantics, marketing phonosemantics, naming, brand name, experimental phonosemantics, neologism.

\section{Introduction: Marketing phonosemantics}

The new term marketing phonosemantics, the principles of which should help create new effective and memorable brand names, appeared at the beginning of the $21^{\text {st }}$ century (Куцерубов 2011). The main point of marketing phonosemantics is its potential for using sounds as a tool of influence on the consumer. The audible difference in sounds and its perception can be used in brand naming, slogans, and creation of advertising texts because the knowledge of these differences can help the author generate the needed insight in order to anticipate the desired associations, which can be subsequently referenced exactly to the core audience (Володина 2011; Куликова 2008; Шестакова, s.a.). 
The mechanisms of creating neologisms in linguistics resemble the methods used in marketing when a new brand name is created (Названова 2013; Скок 2011; Уланович 2013; Ягафарова 2014). One of the naming stages in marketing is phonosemantic analysis. It is not only described in marketing course books and taught in universities but is also used by marketing specialists intuitively. The real potential of phonosemantic analysis in solving naming problems in marketing should be proved linguistically.

According to the common opinion shared by marketing specialists, an appropriate name raises sales and forms a positive image of the company (Андреева 2003). It is generally admitted that a brand name should sound soft. Any word, especially a neologism, may be pleasant or unpleasant to the ear (Кожанова 2007). Nonetheless, experimental researches in the sphere of the potential of Russian marketing phonosemantics in solving naming problems have yet to be held.

It is also said that human reaction to a word as a sequence of sounds is subconscious and can be seen as an emotional tone. Osgood (1967) was the first to investigate this phenomenon. Later Zhuravlev (Журавлев 1974; 1991) discovered these subconscious meanings for the Russian language. A lot of experiments have already proved the existence of the phenomenon of phonosemantics in isolation, without reference to their practical implementation. Therefore, the question of the potential of phonosemantics in the sphere of modern marketing has yet to be explored.

Communication in the life of a modern person is connected to a great extent with media and with advertising in particular. An advertisement message is a special type of text where the main idea can be hidden "between the lines" (Ягодкина et al. 2014). It can be conceived in a similar way to fictional literature where specific feelings can be decoded with the help of different literary devices. As the main purpose of an advertising message is to sell, it should have a significant influence on the recipient. 
Stashko (2017: 303) points out that "many researches demonstrate certain similarities in the way individuals perceive the relationship between language sounds and sensory impressions". Thus, the data collected is important for the current research and is the basis for the experiment set-up.

Within the preliminary experiment (the first stage of the experiment out of two), associations of different respondents with each of the 4 neologisms studied (the word combination fantasy word (Auracher et al. 2011) is used in the current experiment to specify the term neologism in order to show that the fantasy words were created specifically for the experiment) should be compared. Will these associations be the same for a group of people or will there be only unmatched individual associations? If the first is true, can we control and predict these associations? Or can we advisedly influence potential customers with the help of phonosemantics and manipulate our target audience? The paper answers these questions and shows if the linguistic phenomenon of sound symbolism has potential in marketing, how it can be used in practice, and what factors can influence fantasy word perception besides the sounding of the word.

\subsection{Background of experimental phonosemantics}

In order to set up our experiment, a review was done of the preceding experiments in phonosemantics (Братчикова 2011; Magnus 2001; Wagner, s.a.). It was important to survey not only the results but also to examine the logic of the research, and to understand how it could be transformed in relation to the process of naming and brand name perception.

Successful experiments in phonosemantics are connected mainly with round-angular sound symbolism and size sound symbolism. The word "successful" here means that the results were the same in the independent experiments done by different researchers in different parts of the world over a long period of time (Kovic et al. 2010 - for the 
English language; Ramachandran \& Hubbard 2011 - for the English language; Shinohara \& Kawahara 2012 - for the English, Chinese, and Japanese languages).

Neuroscience helped to extend knowledge about both types of sound symbolism (round-angular and size symbolism), as it has helped us understand how the human brain works with language. Sound symbolism here is connected with the phenomenon of synaesthesia. It was investigated by Ramachandran in the late 1990s and early 2000s (Wagner, s.a.). Earlier, in 1947, Kohler did an experiment (Auracher et al. 2011), where he showed the respondents two figures - of round and angular shape - and asked, which one they would call "maluma" and which one "takete". The majority of respondents answered that "maluma" had a round shape and "takete" had an angular shape. Ramachandran repeated that experiment but replaced the words with "bouba" and "kiki". The results are explained by the effect of synaesthesia, an ability to create cross-modal abstractions (to make an analogy between different senses). Therefore, the acoustics of the word "bouba" was paired with a round shape and that of "kiki" with an angular shape.

In 2004, Westbury continued these studies (Wagner, s.a.). The respondents were given words (existing in the English language and newly coined fantasy words) in different frames - round and sharp. Each word could be found twice in round and angular frames. The participants were asked to decide quickly, which word was real. The reaction time was also measured in that experiment. The results showed that the participants spent less time on recognizing the word when the frame and the sounding of the word were compatible according to the hypothesis. Westbury in the next experiment decided to lessen the role of semantics and to use only letters instead of words, which were surrounded by frames as before. One of the important points of this experiment is that the respondents were not informed about the purposes of the test, nor were they informed about sound symbolism. Therefore, the results cannot be contradicted and interpreted as forced. The conclusion of the experiment is the confirmation that round-angular symbolism exists and it can be useful when the role of 
semantics in the word is inconspicuous: for example, in neologisms or in the process of language acquisition. For the current experiment centering on brand naming and described in this paper, it was crucial that only experiments with words without a referent or else fully unknown lexical items be seen as conclusive because when the respondents know the word and its meaning, there is no need to use phonosemantics (round-angular or size symbolism).

In 2010, Kovic, Plunkett, and Westermann did an experiment similar to Kohler's (Wagner, s.a.). The words for the round and angular objects were "riff" and "mot". The reaction time was also measured. The results again proved Kohler's theory. The respondents were similarly asked after the test if they knew anything about phonosemantics. The participants answered that they were unfamiliar with phenomenon of sound symbolism. As the researchers were interested in neurology, they supposed that if round-angular and size sound symbolism were psychologically applicable, then not only the reaction time would be faster but also there would have to be a difference in neuron activation. They did the same experiment but changed the words to "schick" and "dom", which were thought to be more sound symbolic and used EEG (electroencephalography). The signatures appearing from sound-symbolic and non-sound symbolic conditions were different after the demonstration of a visual object. The congruent associations caused a "negatively peaking wave". It is not known what this difference in signatures indicates but this fact suggests the existence of sound symbolism.

In 2010, another experiment similar to Kohler's was done by Ahlner and Zlatev (Wagner, s.a.). Participants were required to match the neologism and the picture. Only one model was used for the neologisms - CVCV (e.g., lili/lulu or kiki/gigi) and the syllable structure was identical. The results were expected and proved Kohler's theory again. Moreover, it was explained that roundness and angularity correspond mostly to consonants and size symbolism specifically to vowels. 
A well-known experiment for size symbolism was done by Sapir, who created two new English words - "mil" and "mal" (Coombes 2014). The participants of his experiment answered a question about the quality of the table - which was large and which was small - "mil table" and "mal table". The majority answered that "mil" is connected with small and "mal" is connected with large. It is obvious that people really have a symbolic feeling for these two vowels. It can be explained by articulation (the opened or nearly closed mouth when pronouncing these two sounds) or acoustics ("a" sounds louder than " $\mathrm{i}$ " as the tongue position is lower and the mouth is more opened), so this explanation refers to objective sound symbolism. Since Sapir wanted to understand if it was a universal phenomenon or a product of the English culture, he continued the experiment, testing the same question on Chinese participants. He wanted to understand whether it was a universal phenomenon or a product of the English culture. The results were similar to the previous ones, and that proved universality of the phenomenon.

In 2010, more researchers, Shinohara and Kawahara, studied sound symbolism in the English, Chinese, Japanese, and Korean languages (Wagner, s.a.). The idea for the experiment was to find out if Sapir's size symbolism was a cross-linguistic phenomenon. The respondents were asked to give a mark from 1 to 4 according to their feelings for the size of each sound. The results proved that the phenomenon was really cross-linguistic; however, for people of different countries, the main reasons behind choosing the "big" or "small" label were also different: vowel height was the most important quality for the Chinese speakers and vowel backness, for example, for the English speakers.

In 2011, Thompson and Estes decided to continue the studies on size symbolism (Wagner, s.a.). The respondents were given pictures of different size and the neologisms, which they could choose to describe the images. As they saw that the visual length of the word influenced the participants (the visually longer words coincided with the larger images), the researchers decided to repeat the experiment so 
that the respondents could perceive the words audibly. This produced the same results as the previous test, substantiating their hypothesis.

The prior experiments prove that the phenomenon of sound symbolism exists. Nevertheless, the main point of the experiment described in this paper is to understand how phonosemantics "works" in the sphere of brand name creation and how it fulfills its potential there.

\section{The use of different types of phonosemantics in marketing}

Phonosemantics is divided into two main branches: objective and subjective phonosemantics (Данильчук 2016). Objective phonosemantics is divided into:

- synthetical sound symbolism (iconism);

- conventional sound symbolism (phonesthesia);

- productive sound symbolism (onomatopoeia).

Synthetical sound symbolism (iconism) is the product of the synaesthesia effect as a person's capability to make cross-modal abstractions bridging non-related characteristics (e.g., colour and shape). The existence of synthetical sound symbolism is proved by the experiments held by Sapir (1929), Kohler (1947), and Ramachandran (2001), all described above. This phenomenon is usually explained both by acoustics and articulation. If iconism is used consciously in the field of marketing while creating new brand names, it is possible to associate fantasy words with some specific characteristics like size or shape, etc.

Conventional sound symbolism (phonesthesia) is studied with the help of etymologic analysis. The main idea of phonesthesia is that any word containing some specific phoneme has its specific connotation. It was identified within the phonesthesia experiment that, for instance, the phonestheme "gl" appears in English words in the semantic field "light" (Magnus 2001). It can be assumed that concrete phonesthemes can be used in the creation of fantasy words functioning as brand names. 
Productive sound symbolism (onomatopoeia) complies with the rules of the Russian language. It is the most visible and evident type of phonosemantics, which is produced consciously. Different onomatopoetic words are used in video and audio advertising (e.g., Schweppes (the onomatopoeia is intensified by being pronounced imitating the sound of an opening bottle like "Schschschwepssssss"), Mazda zoom-zoom).

Subjective phonosemantics exists due to the synaesthesia effect but it cannot be explained objectively by acoustics or articulation. It is the question of subconscious feeling associated with word perception, like pleasant or unpleasant, positive or negative, etc. Subjective phonosemantics is based on the method of semantic differential (Osgood 1967). In marketing, it works the following way: a fantasy word sounding French feels like something romantic and may well serve to name beauty products and services; a fantasy word sounding German feels strong, strict and suitable for naming some equipment.

All the types of phonosemantics are important for marketing. As far as the experiment described in this paper is concerned, the synthetical sound symbolism (iconism) in marketing is researched. Subjective phonosemantics is not the aim of the research but will also be involved because of the peculiarities of the experiment, connected with the method of receiving data described below.

\section{The material, methods, and aim of the experiment proving the potential of phonosemantics in brand name creation}

If there is a hypothesis that the sounding of fantasy words is the principal source of information for the customer, fantasy words require experimental evaluation. An experiment proving the potential of phonosemantics in solving naming problems should be conducted on a massive group of people of different occupations, age, and gender by means of the crowdsourcing method. The term "crowdsourcing" was first coined in the magazine "Wired" (Howe 2006b) in January, 2006. After half a year, the author of the term, Howe (2006a), admitted that he had not expected that both the term 
and the method it designated would spread so fast. In this paper, the term crowdsourcing means the involvement of respondents on the Internet on a voluntary basis in order to collect data during a linguistic experiment. It is psychologically easy for a respondent to participate in a crowdsourcing project because the project is uploaded onto the Internet, which is currently the most popular and demanded source of communication (Ивашнева 2014; Курочкин 2013; Панкрухин 2011; Kietzmann 2016).

The material for the analysis is the answers of respondents to a specially designed questionnaire. A survey aimed at collecting phonosemantics data must be elaborated very carefully in view of the correlation between the anticipated answers and the aim of the experiment. Accordingly, the main tasks are to understand if the generator of the name can hide any specific associations "between the lines" with the help of the sounding of the fantasy word, and to establish if these associations will be perceived in the same way by the respondents (potential customers).

The target audience of the experiment is the inhabitants of the Russian Federation and specifically those whose mother-tongue is the Russian language.

The experiment is divided into two parts:

1) preliminary experiment by using the focus group method;

2) main experiment by employing the crowdsourcing method.

The preliminary experiment shall help analyze:

1) if the expectations from the experiment meet the preliminary results;

2) if the questionnaire should be corrected (the design, the number of questions, etc.);

3) if the respondents are motivated enough to answer the questions. 
The preliminary experiment gives an opportunity to discuss the answers with the respondents, to see their reactions, to understand the logic of their answers as well as their attitude to the quality and number of questions, the questionnaire design, and the time taken for answering. A suitable method for this purpose is the focus group method (Дмитриева 1998).

These primary results were very important for the success of the main experiment using the crowdsourcing method and would help avoid any possible mistakes. The results were processed by methods of statistical linguistics.

\section{Fantasy words used in the experiment}

It is hypothesized that when a customer hears a fantasy name, he/she is mostly focused on its phonetic characteristics. A fantasy word is a newly constructed word (Auracher et al. 2011). We can conclude that a brand name that enters the foreign market without translation can act as a fantasy word for customers if one does not know the meaning of the word and hears it for the first time. This problem is connected with brand name translation (Данильчук 2017). The famous Russian car brand "Zhiguli" (Жигули) made a mistake when it decided to enter the foreign market with that brand name not only because the word was difficult to pronounce for Europeans but also because it had some consonant-related associations with obscene words in several European languages. Then the brand name was changed to "LADA". A well-timed analysis can help prevent negative associations and cause positive ones in the customer's mind. A brand name shall be memorable and attract attention, which can be achieved with the help of phonosemantics (alliteration, rhyme, etc.). It is said that a brand name should not provide false expectations and is expected to clearly identify the product or service because the name is included in the system of communication with the customer and it is the first thing that gives information about the brand (Вегенер 2012). Sometimes brands provide deceitful expectations because of their foreign name sounding while, in fact, the products are produced in China or Russia: Bork, Mr. Ricco, Incity, Savage, Sela, Gloria Jeans, Gee Jay, etc. These names try to raise the prestige of the goods 
because of the stereotype on the Russian market that a product produced in a foreign country is always of a high quality. There is also another tendency connected with the fact that the name of the product in the Russian language raises patriotic feelings and makes the customer proud of these goods and services. Therefore, the name in any language shall provide the appropriate positive associations, and the ideas put by the creator into the fantasy word with the help of its sounding are meant to be recognized by the customer in the same way.

The main goal for brand holders is to understand how to create fantasy words, which will be suitable for current market conditions and still comply with the product description supplied by the creator. Also it is still not clear what characteristics can be put into the sounding of the word by the creator of the brand name and understood by the customer in the same way. The linguistic experiment described in this paper answers these questions.

The hypothesis that is tested by the experiment indicates that different people can have the same feelings or associations in perceiving the sounding of unknown, fantasy words, which, as a consequence, confirms the possibility of putting hidden or additional meanings into the words. That can be useful, especially in the process of naming new products or services and their subsequent entry to the market.

Two pairs of contrastive fantasy words, Eveloun - Zippeg and Tikiton - Raola, were chosen to test the hypothesis during the preliminary experiment. Each pair belongs to a specific type of synthetical sound symbolism: the first pair - to round-angular symbolism and the second - to size symbolism.

The first pair Eveloun - Zippeg has already been tested in a phonosemantics experiment, which was launched by Zhuravlev (Журавлев 1991), the founder of experimental phonosemantics in Russia. In his experiment, the respondents were asked to match two pictures representing lakes - with round and angular shores - with the 
fantasy words. The experiment showed that the majority of the respondents thought that the word Eveloun was suitable for the lake with a round shore and the word Zippeg for the lake with an angular shore. Therefore, the author concluded that Eveloun is a "round word" and Zippeg is an "angular word". In fact, similar experiments were held with the word pairs maluma - takete and kiki - bouba, which were described above. The idea of the current experiment is to test how Zhuravlev's fantasy words will function in relation to the names of products and services and to find out whether these associations, caused by the phenomenon of sound symbolism, can be in the same priority or some other factors will affect them.

The second pair Tikiton - Raola was created by analogy with the experiment connected on size symbolism, where the sound /I/ appears smaller than the sound /a/ in a pair of Sapir's fantasy words mil - mal (Coombes 2014). The task was to create two contrast words where one would contain mostly close, narrow vowels and the other - mostly open, broad vowels.

Both pairs of fantasy words were written in Russian in the following way: Эвелоун Зипnег (Eveloun - Zippeg), Тикитон - Раола (Tikiton - Raola). The description of the fantasy words used in this experiment is represented in Table 1.

Table 1. Description of the fantasy word pairs used in the preliminary experiment

\begin{tabular}{|c|c|c|c|c|}
\hline $\begin{array}{c}\text { Contrastive } \\
\text { fantasy words }\end{array}$ & $\begin{array}{c}\text { Type of } \\
\text { phonosemantics }\end{array}$ & $\begin{array}{c}\text { Type of sound } \\
\text { symbolism }\end{array}$ & $\begin{array}{c}\text { Author of a } \\
\text { fantasy word } \\
\text { pair }\end{array}$ & $\begin{array}{c}\text { Examples of } \\
\text { previous } \\
\text { experiments }\end{array}$ \\
\hline $\begin{array}{c}\text { Eveloun - } \\
\text { Zippeg }\end{array}$ & $\begin{array}{c}\text { synthetic sound } \\
\text { symbolism (iconism) }\end{array}$ & $\begin{array}{c}\text { round-angular } \\
\text { symbolism }\end{array}$ & Zhuravlev & $\begin{array}{c}\text { maluma and } \\
\text { takete (Kohler); } \\
\text { kiki and bouba } \\
\text { (Ramachandran, } \\
\text { Hubbard) }\end{array}$ \\
\hline Tikiton - Raola & $\begin{array}{c}\text { synthetic sound } \\
\text { symbolism (iconism) }\end{array}$ & $\begin{array}{c}\text { size } \\
\text { symbolism }\end{array}$ & Danilchuk & $\begin{array}{c}\text { mil and mal } \\
\text { (Sapir) }\end{array}$ \\
\hline
\end{tabular}

The fantasy words were referred to the brand names of different goods and services, and used in the questions testing the hypothesis of the research. 


\section{Phonosemantics experiment and its results}

\subsection{Preliminary experiment}

The respondents in the preliminary experiment were 34 students aged 21 to 22 (from the philological faculty of Herzen State Pedagogical University of Russia).

The respondents were asked to fill in a form containing 14 questions and write explanations for their answers, which were discussed in a focus group after all the questionnaires were collected. The task was to answer, which of the proposed names were suitable for the different goods and services. All the questions were closed, therefore the respondents could only choose A or B from the set of questions situated randomly on the form. The random order anticipated any influence on the respondents' choice because contrast items were not placed side by side (e.g., remembering the answer about a woman's perfume can influence the answer on a man's cologne).

Here is the list of questions and possible answers to check the potential of roundangular symbolism:

1. Which name is suitable for a health center for the elderly?

2. Which name is suitable for milk chocolate?

3. Which name is suitable for a man's perfume?

4. Which name is suitable for cheese spread?

5. Which name is suitable for a cream donut?

6. Which name is suitable for a recreational center specializing in extreme sports?

7. Which name is suitable for dark chocolate?

8. Which name is suitable for a woman's perfume?
A. Eveloun
B. Zippeg

And the list of questions and possible answers to check the potential of size symbolism is as follows: 
9. Which name is suitable for a small café?

10. Which name is suitable for a company engaged in townhouse (low-rise flat blocks) construction?

11. Which name is suitable for a big concert hall?

12. Which name is suitable for a tall fairy-tale character?

13. Which name is suitable for a business centre situated in a skyscraper?

14. Which name is suitable for a short fairy-tale character?
A. Tikiton
B. Raola

Also the respondents were asked to leave explanations for their choice where it was possible. After collecting all the forms, there was a focus group discussion in order to understand the logic of the respondents' answers in more detail. The results are partly represented in Table 2.

Table 2. Examples of the respondents' choice explanation

\begin{tabular}{|c|c|c|}
\hline $\begin{array}{l}\text { Goods and } \\
\text { services }\end{array}$ & $\begin{array}{l}\text { Respondent's explanation of the } \\
\text { fantasy word appropriateness }\end{array}$ & $\begin{array}{l}\text { Respondent's explanation of the } \\
\text { fantasy word inappropriateness }\end{array}$ \\
\hline $\begin{array}{l}\text { health center } \\
\text { for old people }\end{array}$ & $\begin{array}{l}\text { Eveloun is a soft-sounding word for } \\
\text { gentle people; } \\
\text { Eveloun is associated with a glade, } \\
\text { milk, and a cow; } \\
\text { Eveloun just sounds lovely. }\end{array}$ & $\begin{array}{l}\text { Zippeg is associated with a } \\
\text { concentration camp; } \\
\text { Eveloun sounds like the English } \\
\text { "forever alone". }\end{array}$ \\
\hline $\begin{array}{l}\text { big concert- } \\
\text { hall }\end{array}$ & $\begin{array}{l}\text { Sounds "a" and "о" in Raola standing } \\
\text { nearby come across as something } \\
\text { massive; } \\
\text { Raola sounds like something big and } \\
\text { rolling; } \\
\text { The name Tikiton resembles the } \\
\text { Russian word "титан" (giant); } \\
\text { Tikiton is masculine in Russian and } \\
\text { "концертный зал" (concert-hall) is } \\
\text { masculine tоo. }\end{array}$ & $\begin{array}{l}\text { Tikiton resembles the English word } \\
\text { "tiny". }\end{array}$ \\
\hline $\begin{array}{l}\text { short fairy-tale } \\
\text { character }\end{array}$ & $\begin{array}{l}\text { Tikiton sounds like something little; } \\
\text { The word Raola is shorter than } \\
\text { Tikiton; } \\
\text { Raola sounds like "ravioli", something } \\
\text { little. }\end{array}$ & \\
\hline
\end{tabular}


The majority of the respondents marked the sounding of the fantasy word (e.g., soft, liquid, sharp-sounding). The respondents also had consonant-related associations (caused by the sounding similarity, e.g., Raola - ravioli, royal; Tikiton - tiny, titanium) and rhyme associations (e.g., Eveloun-forever alone), and they were the same among the homogenous audience. However, if the reaction to the sounding of the word is more or less uniform, the consonant-related and rhyme associations with each fantasy word may change in accordance with the context. For example, in the context of a health center for the elderly there was a repeated rhyme association "Eveloun - forever alone", but it was the only negative association with this word; in all the other contexts, the respondents ignored it and had positive associations. The respondents who were familiar with different languages (e.g. the fantasy word Zippeg sounds like a German word, Raola sounds like a Finnish word) made stereotypical conclusions about the characteristics of the product or service (e.g., a German product has a high quality, a Finnish brand can be appropriate for a company engaged in construction, etc.) according to these connections. For example, in reality it can be seen that all the wellknown perfume shops are named in a French-like style: L'Etoile (Л'Эmyaль), Rive Gauche (Рив Гои), Ile de Beauté (Иль де Ботэ) because the French language is always associated with fashion and cosmetics.

The other reason for this phenomenon is connected with the term artlangs (Coombes 2014), which is created with the help of two words - "artistic" and "language". Artlangs are languages able to provide aesthetic pleasure because of their sonority. Hence, artlangs unite pleasant sounding languages. They can also be fantasy languages like Tolkien's Elvish because their creators forget about semantics and mostly focus on how they sound. Artlangs creators are similar to poets because they can forget about language rules and create their own fantasy words, for example, the Russian futurists, who harmonized literature with music in their poetry. In fact, they created words without meaning and relied on their sonority as the only means of forcing feelings and emotions in people (Coombes 2014). Thus, French is always presented as the most beautiful, romantic, and emotional language. However, this does not mean that other 
languages cannot be used for the names of goods and services. The German and Finnish languages can be used for naming goods and services in order to show the high quality of the latter and establish trust, the Italian language is suitable for food and restaurants, etc. A fantasy word, which may sound like French, German or Italian, can provide associations with the "right" country and manipulate the customer in the best way for the brand holder.

In a lesser degree, the respondents mentioned the non-phonetic characteristics which are nevertheless also important when a new brand name is created: speed of articulation (Tikiton is pronounced quickly, that is why it is appropriate for a small café), word length (Tikiton is a long word, that is why it is appropriate for a tall fairy-tale character), word gender (Tikiton is masculine, Raola is feminine, concert hall is masculine, that is why Tikiton is appropriate for the concert hall). One respondent explained that he imagined how the name could be written on billboards, leaflets, and packages, and gave the answers according to the appropriateness of the graphic of the word for the product or service. However, the non-phonetic characteristics influenced the respondent's choice less than phonetic ones.

The explanations obtained during the discussion indicated the focus of respondents' reactions to a fantasy word (Fig. 1). 


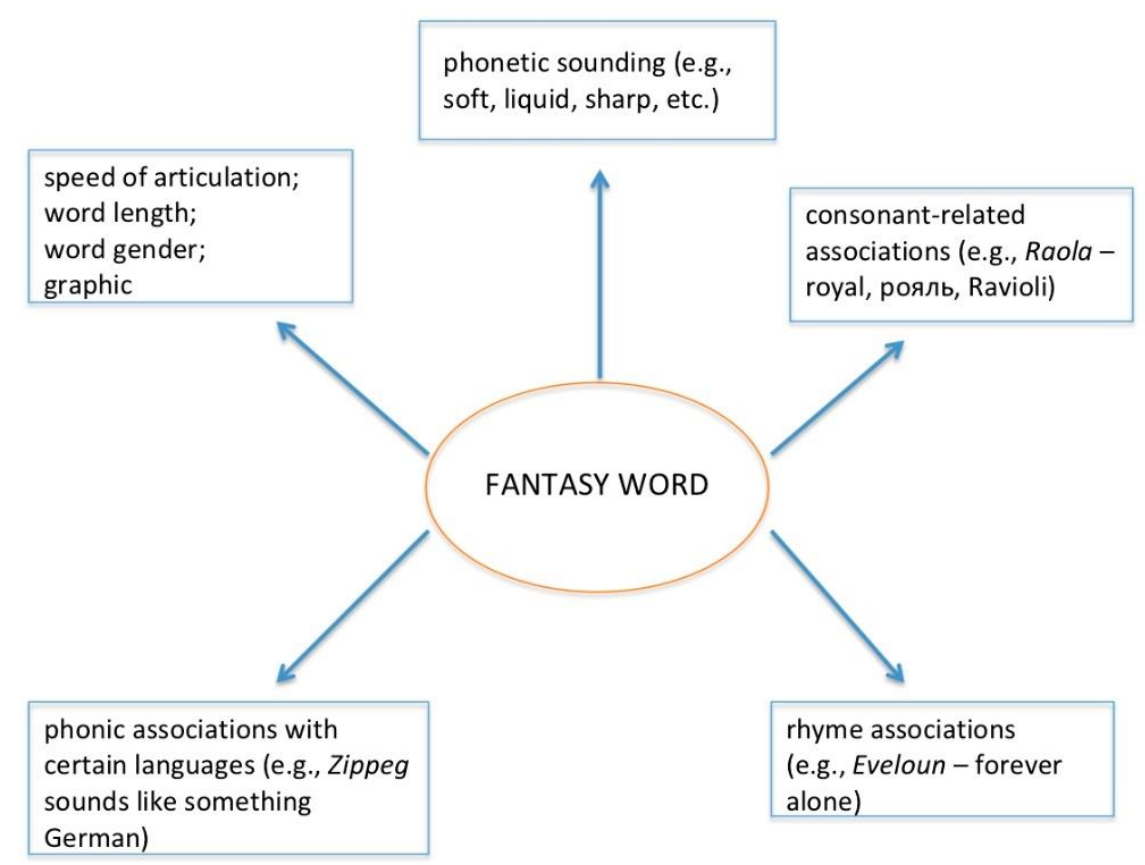

Figure 1. Focus of respondents' reactions to a fantasy word

Despite the fact that these were only the results of the preliminary experiment, they gave understanding of the possible logic behind the respondents' answers. The preliminary experiment itself provided an opportunity to improve the design and quality of the questionnaire and to prevent possible mistakes in the main experiment done in a massive group of people by means of crowdsourcing. The crowdsourcing method is the most suitable if the aim of the experiment requires expanding a small group of respondents to a large group of Internet users (Шуровьески 2007). The most important factors for the main experiment are the design of the questionnaire, quality of questions and respondents' motivation (Čibej et al. 2015).

\subsection{The main experiment}

For the validity of the main experiment it was decided to add questions with two new pairs of words: Лиовьель - Бритринг (Liovielle - Britring) for testing round-angular symbolism and Ринти - Гауварра (Rinti - Gauvarra) for testing size symbolism. In addition, it was decided to add questions with an open answer because there was not any opportunity to ask each respondent to explain their choice during the discussion 
like in the preliminary experiment. As a result, the number of questions was expanded to 36. All the questions were put on the platform Google Forms and the link was shared on different social media platforms like Facebook.com, Vk.com, etc. Google Forms was chosen for the experiment because it gives an opportunity to collect data without a fee and has different ways of presenting data: pie charts, diagrams, etc., which can be exported to Excel. Additionally, the questionnaire was tested on two respondents (a man and a woman, who had not participated in the preliminary experiment), in order to check that the platform worked well, the answers were fixed, and the time slot for answering was comfortable. Both respondents answered the questions in 10 minutes and that was a comfortable time for them.

An online calculator (Социология по-новому, s.a.), a tool of linguistic statistics, was used to count the sample - the quantity of respondents needed to answer the questions in the form so that the answers could be extrapolated to the parent population. The online calculator counted that as many as 666 respondents would be enough for the highest percentage of experimental accuracy. For an additional control, the "snapshot" of the results is made: the first stage - after 300 answers, the second stage -600 answers, and more if needed. The statistics should be compared at each stage. If the quantity of answers increases and there is no fundamental difference in the results (breakdown of percentage), this indicates that the experiment can be finalized. At the moment, the experiment is at the first stage (302 answers in total) and these statistics are partly presented below (the number of answers can be different as the respondents had an opportunity to skip questions). In addition, knowing the results of the preliminary experiment can greatly substantiate the initial claim and predict that at the second stage there will be no significant changes. However, the more answers will be received, the more accurate the results of the experiment will be.

Each question and answer were analyzed by means of comparing the idea of the generator of the fantasy name and the respondents' associations caused by the fantasy name. Moreover, it was important to observe the percentage ratio of the answers: if the 
reactions to the stimuli (fantasy names) can be the same in a massive group of people. The representation of the results includes the statistical data counted by Google Forms automatically.

Here are two examples of results representation for round-angular symbolism:

Question: Which name is suitable for a woman's perfume?

Expected answer: Eveloun.

Reason: a "rounded word" is associated with the soft, feminine qualities.

Results of the preliminary experiment: Eveloun (32 answers) - Zippeg (2 answers).

Results of the experiment by means of crowdsourcing: Eveloun $89.9 \%$ - Zippeg $10.1 \%$.

Question: Which name is suitable for a man's cologne?

Expected answer: Zippeg.

Reason: an "angular word" is associated with firm, masculine qualities.

Results of the preliminary experiment: Eveloun (11 answers) - Zippeg (23 answers).

Results of the experiment by means of crowdsourcing: Eveloun $81.5 \%$ - Zippeg $18.5 \%$.

Examples of results representation for size symbolism are as follow:

Question: Which name is suitable for a short fairy-tale character?

Expected answer: Rinti.

Reason: close narrow vowels in the word are associated with little things.

Results of the experiment by means of crowdsourcing: Rinti $92.9 \%$ - Gauvarra 7.1\%.

Question: Which name is suitable for a tall fairy-tale character?

Expected answer: Gauvarra. 
Reason: open wide vowels in the word are associated with big things.

Results of the experiment by means of crowdsourcing: Rinti (9.2\%) - Gauvarra $(90.8 \%)$.

The main experiment percentage ratio is partly represented in the figures below (see Fig. 2 and Fig. 3).

\section{Which name is suitable for a woman's perfume?}

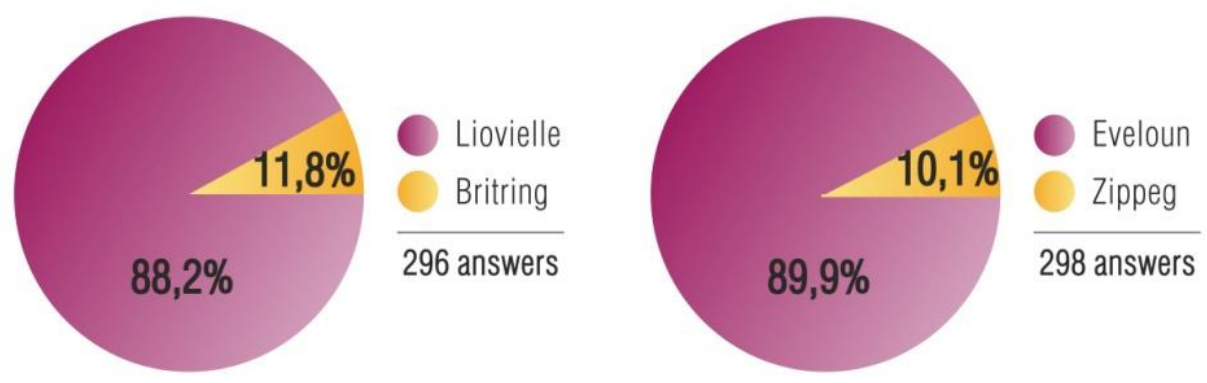

\section{Which name is suitable for a man's perfume?}

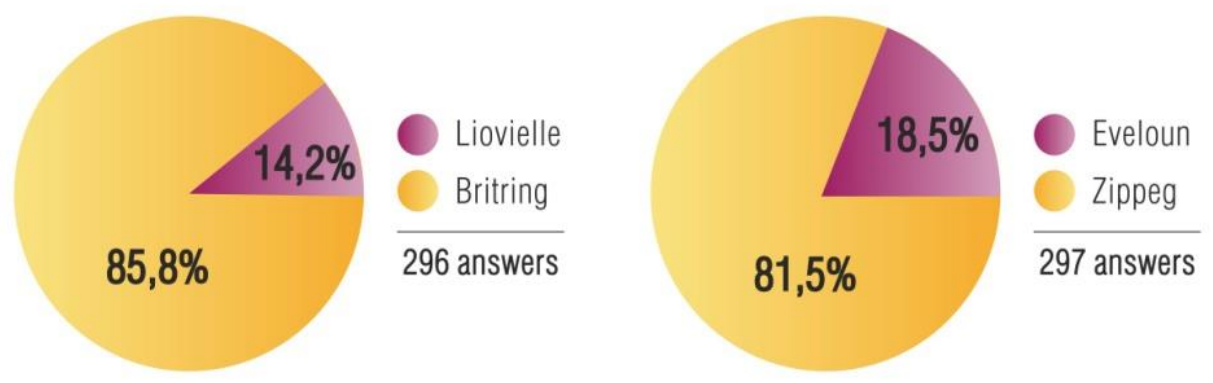

Figure 2. Examples of the percentage ratio of the answers intended to check round-angular sound symbolism 


\section{Which name is suitable for a short fairy-tale character?}

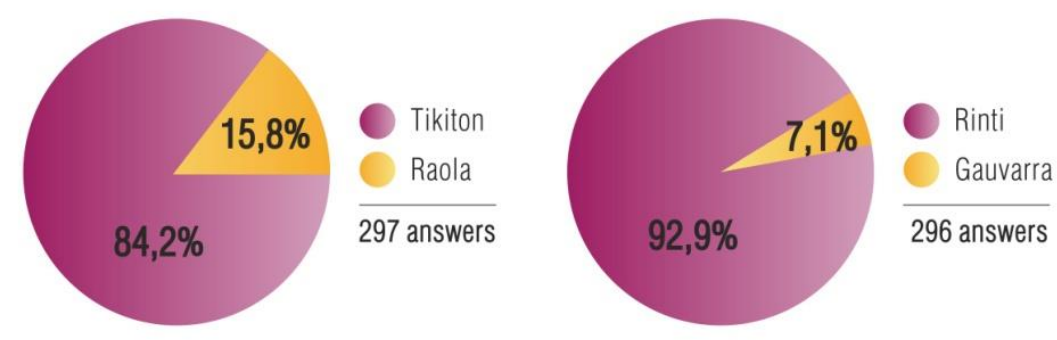

\section{Which name is suitable for a tall fairy-tale character?}

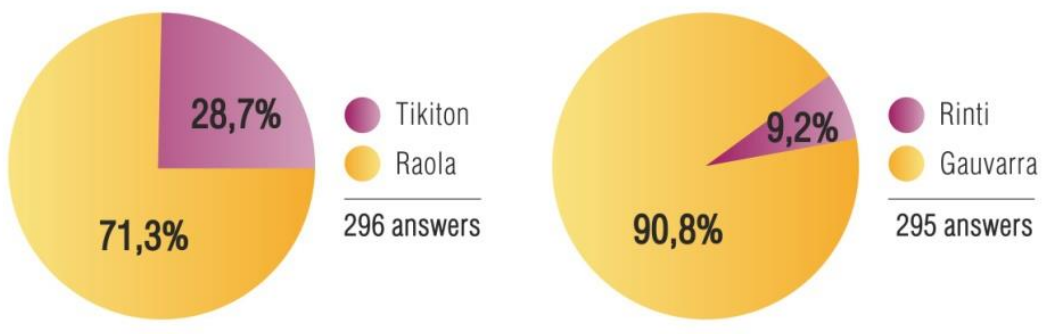

Figure 3. Examples of the percentage ratio of the answers intended to check size symbolism

The expected answers were a match for all the respondents in every question related to round-angular symbolism and the percentage ratio was very high. Several respondents during the discussion within the preliminary experiment mentioned that they would not prefer the word Zippeg for any of the items because of its unpleasant sounding: this explains a slight deviation in the experiment, namely in the question concerning a man's cologne, when the answer Zippeg is more expected.

However, in certain questions checking size symbolism, the answers of the respondents reached the expected answers with limitation. The size contrast in the pair of fantasy words Tikiton - Raola was less evident for the respondents than in the pair Rinti Gauvarra. The possible explanation is that in the pair Tikiton - Raola (where Tikiton is expected to be something small and Raola is expected to be something large) the contrast is not so evident and is influenced by other factors such as: 
1. the influence of round-angular symbolism (Raola is a "rounded word" and can also be associated with something cosy and pleasant);

2. the length of the word (for some respondents Tikiton is "bigger" than Raola because the word Tikiton is longer);

3. phonic associations with certain languages (Raola is associated with something Finnish that can be felt like something of a high quality);

4. speed of articulation (Tikiton is pronounced more quickly than Raola).

After the set of closed questions in the questionnaire, the respondents were asked 8 open questions: they had to write several attributes, which could describe the words Eveloun, Zippeg, Liovielle, Britring, Tikiton, Raola, Rinti, and Gauvarra. When the respondents were requested to give several attributes associated with each of the words in isolation, without reference to any specific goods or services, the associations were nearly the same for $90 \%$ of the respondents. Here are the examples of respondents' answers in Table $3-10$ (10 answers chosen at random for each fantasy word from the whole list of answers are given below in the original language with translation).

Table 3. Associations with the fantasy word Eveloun

\begin{tabular}{|l|l|}
\hline \multicolumn{1}{|c|}{ Association } & \multicolumn{1}{c|}{ Translation } \\
\hline плавное, приятное & smooth, pleasant \\
\hline нежное & tender \\
\hline плавное & smooth \\
\hline тягучее, плавное & viscous, smooth \\
\hline $\begin{array}{l}\text { мягкое, 'тянучее', пышное, } \\
\text { спокойное }\end{array}$ & soft, viscous, gorgeous, calm \\
\hline мягкое, нежное & soft, tender \\
\hline $\begin{array}{l}\text { мягкое, обтекаемое, светлое, } \\
\text { теплое }\end{array}$ & $\begin{array}{l}\text { soft, flowing-shaped, light, } \\
\text { warm }\end{array}$ \\
\hline $\begin{array}{l}\text { большое, округлое, нежное, } \\
\text { приятное }\end{array}$ & large, rounded, tender, pleasant \\
\hline плавное & smooth \\
\hline нежное, ласковое, мягкое & tender, gentle, soft \\
\hline
\end{tabular}

As it is clearly seen, all the respondents have the same feeling about the fantasy word Eveloun and their further associations have the same tendency: positive associations 
with something rounded, soft, tender, and light. These associations correlate with the respondents' choice while answering the closed questions.

Table 4. Associations with the fantasy word Zippeg

\begin{tabular}{|l|l|}
\hline \multicolumn{1}{|c|}{ Association } & \multicolumn{1}{c|}{ Translation } \\
\hline острое, угловатое & pointed, angular \\
\hline острое & pointed \\
\hline $\begin{array}{l}\text { немецкое, резкое, мужское, } \\
\text { сильное }\end{array}$ & German, sharp, masculine, strong \\
\hline брутальное, мужское & brutal, masculine \\
\hline резкое, твердое & sharp, firm \\
\hline резкое, острое & sharp, pointed \\
\hline твердое, резкое, решительное & firm, sharp, decisive \\
\hline $\begin{array}{l}\text { четкость, твердость, } \\
\text { бескомпромиссность }\end{array}$ & $\begin{array}{l}\text { precision, firmness, uncompromising } \\
\text { attitude }\end{array}$ \\
\hline точное, четкое, специальное & exact, precise, specialized \\
\hline $\begin{array}{l}\text { немецкое, твердое, грубое, } \\
\text { экстремальное }\end{array}$ & German, firm, coarse, extreme \\
\hline
\end{tabular}

The other answers are also similar. Hence, for Zippeg, the most common associations are with something firm, pointed, masculine, and German. These associations coincide with the respondents' choice while answering the closed questions.

Table 5. Associations with the fantasy word Liovielle

\begin{tabular}{|l|l|}
\hline \multicolumn{1}{|c|}{ Association } & \multicolumn{1}{c|}{ Translation } \\
\hline французское, изящное & French, exquisite \\
\hline $\begin{array}{l}\text { мягкое, плавное, доброе, } \\
\text { красивое }\end{array}$ & soft, smooth, kind, beautiful \\
\hline $\begin{array}{l}\text { французское, напоминает имя } \\
\text { Лион }\end{array}$ & French, like the name Lyon \\
\hline европейское, тёплое, ветреное & European, warm, windy \\
\hline мягкое, изысканное, французское & soft, elegant, French \\
\hline $\begin{array}{l}\text { французское, вкусно пахнущее, } \\
\text { разноцветное }\end{array}$ & French, smells good, colourful \\
\hline изысканное & exquisite \\
\hline $\begin{array}{l}\text { французское, романтичное, } \\
\text { плавное }\end{array}$ & French, romantic, smooth \\
\hline люксовое & deluxe \\
\hline певучее, женственное, изящное & melodious, feminine, exquisite \\
\hline
\end{tabular}

The most common association for Liovielle is connected with the country of origin of the word - France, so the other reactions stem from the perception of France as a 
country usually connected with romance, love, tenderness, etc. The associations correlate with the respondents' choice while answering the closed questions.

Table 6. Associations with the fantasy word Britring

\begin{tabular}{|l|l|}
\hline \multicolumn{1}{|c|}{ Association } & \multicolumn{1}{c|}{ Translation } \\
\hline жесткое, резкое & rough, sharp \\
\hline деловое, уверенное & business-like, confident \\
\hline резкое & sharp \\
\hline $\begin{array}{l}\text { немецкое, военное, неприятное, } \\
\text { опасное }\end{array}$ & $\begin{array}{l}\text { German, military, unpleasant, } \\
\text { dangerous }\end{array}$ \\
\hline мужское, брутальное, резкое & masculine, brutal, sharp \\
\hline деловое, серое & business-like, grey \\
\hline мужское & masculine \\
\hline немецкое, строгое & German, strict \\
\hline самолет, ружье, тушенка & plane, gun, tinned meat \\
\hline $\begin{array}{l}\text { британское, дорогое, } \\
\text { конкретное }\end{array}$ & $\begin{array}{l}\text { British, expensive, related to } \\
\text { something specific }\end{array}$ \\
\hline
\end{tabular}

The "angular" fantasy word Britring also causes associations connected with something sharp, rough, and pointed, which are similar to the answers for the "angular word" Zippeg. The associated countries of origin are also mentioned - Germany and Great Britain. The associations coincide with the respondents' choice while answering the closed questions.

Table 7. Associations with the fantasy word Tikiton

\begin{tabular}{|l|l|}
\hline \multicolumn{1}{|c|}{ Association } & \multicolumn{1}{c|}{ Translation } \\
\hline маленькое & small \\
\hline $\begin{array}{l}\text { детское, сказочное, летнее, } \\
\text { смешное }\end{array}$ & $\begin{array}{l}\text { childlike, fabulous, summery, } \\
\text { funny }\end{array}$ \\
\hline доброе, крошечное & kind, Lilliputian \\
\hline смешное, забавное, детское & funny, amusing, childlike \\
\hline $\begin{array}{l}\text { название китайской, японской } \\
\text { кухни }\end{array}$ & $\begin{array}{l}\text { name of Chinese or Japanese } \\
\text { food }\end{array}$ \\
\hline неинтересное, скучное, серое & unexciting, boring, grey \\
\hline японское & Japanese \\
\hline большое, важное & large, important \\
\hline русское & Russian \\
\hline напоминает Титаник & reminds of Titanic \\
\hline
\end{tabular}


There are several single associations coming out of the line connected with something small as was expected: single associations with something big and also associations not connected with size symbolism itself (association with Titanic is a consonantrelated association). That means that size symbolism in this case is not so_prominent and there were other important factors that influenced the respondents' associations and also their choice in the closed questions.

Table 8. Associations with the word Raola

\begin{tabular}{|l|l|}
\hline \multicolumn{1}{|c|}{ Association } & \multicolumn{1}{c|}{ Translation } \\
\hline финское & Finnish \\
\hline глобальное, большое & global, large \\
\hline круглое, милое & round, cute \\
\hline женское, эстонское, неспешное & feminine, Estonian, slow \\
\hline "Виола" & "Viola" \\
\hline что-то финское & something Finnish \\
\hline сыр & cheese \\
\hline Италия, круглое, равиоли & Italy, rounded, ravioli \\
\hline овальное, желтое & oval, yellow \\
\hline финская компания & Finnish company \\
\hline
\end{tabular}

The associations are caused by different reasons, which were deduced in the preliminary experiment: sounding, consonant associations, and phonic associations with certain languages. Those respondents who paid attention to phonic associations with the word mentioned Finland and Estonia as the countries of origin, while those who had a consonant-related association (the association with ravioli was the same for a large group of people) named Italy. Some respondents had a consonant association with an existing product - cheese "Viola". Those respondents whose associations were caused by size symbolism defined the word as round and large, which had been expected when creating the fantasy word.

Table 9. Associations with the word Rinti

\begin{tabular}{|l|l|}
\hline \multicolumn{1}{|c|}{ Association } & \multicolumn{1}{c|}{ Translation } \\
\hline $\begin{array}{l}\text { детское, сказочное, маленькое, } \\
\text { звериное }\end{array}$ & $\begin{array}{l}\text { childlike, fabulous, small, } \\
\text { related to animals }\end{array}$ \\
\hline маленькое & small \\
\hline $\begin{array}{l}\text { что-то небольшого размера, } \\
\text { игрушка }\end{array}$ & something of a small size, toy \\
\hline
\end{tabular}




\begin{tabular}{|l|l|}
\hline миниатюрное & miniature \\
\hline $\begin{array}{l}\text { низкое, маленькое, английское, } \\
\text { простое }\end{array}$ & short, small, English, simple \\
\hline маленькое, рыжее & small, gingery \\
\hline миниатюрное, яркое & miniature, bright \\
\hline маленькое & small \\
\hline имя, десерт & name, dessert \\
\hline мультипликационное & animated \\
\hline
\end{tabular}

The fantasy word Rinti in isolation mostly provides associations caused by size symbolism. Compared with the word Tikiton, that is also a small word, Rinti is shorter, pronounced more quickly, hence there are no other significant factors (length of the word, speed of articulation), which can influence the perception of the size feeling of a fantasy word. The associations correspond to the respondents' choice while answering the closed questions.

Table 10. Associations with the word Gauvarra

\begin{tabular}{|l|l|}
\hline \multicolumn{1}{|c|}{ Association } & \multicolumn{1}{c|}{ Translation } \\
\hline экзотическое, дикое, сочное & exotic, wild, juicy \\
\hline непонятное, забавное & unfathomable, amusing \\
\hline твердое & hard \\
\hline фрукт, экзотическое, шаманское & fruit, exotic, shamanic \\
\hline $\begin{array}{l}\text { экзотическое, мощное, сочное, } \\
\text { большое }\end{array}$ & exotic, powerful, juicy, large \\
\hline испанское, мексиканское, яркое & Spanish, Mexican, bright \\
\hline серьезное, высокое, статное & serious, tall, stately \\
\hline $\begin{array}{l}\text { латиноамериканское, кофейное, } \\
\text { теплое }\end{array}$ & $\begin{array}{l}\text { Latin American, coffee-like, } \\
\text { warm }\end{array}$ \\
\hline смелое, кофейное & courageous, coffee-like \\
\hline мексиканское, текила & Mexican, tequila \\
\hline
\end{tabular}

Except for the associations resulting from sound symbolism, the phonic associations with certain countries and the correlations caused by these were prominent. The interrelations in question correlate with the respondents' choice while answering the closed questions.

To summarize the results of the first "snapshot" of the experiment it should be said that the influence of round-angular symbolism is stronger than that of size symbolism. The 
associations caused by size symbolism appear when the fantasy word is given isolated, but when the fantasy word is used in a context related to goods and services, the other factors mentioned in Fig. 1 can become more important for the respondent. As for the round-angular symbolism, it appears both isolated and along with other factors in the questions related to the goods and services. Round-angular symbolism can be the strongest factor for the respondents' perception of the word and generalizations about the goods and services designated, as a consequence. Despite the fact that the results presented above are provisional, it is expected that an increase in the number of respondents will not change the percentage ratio of the answers significantly. Hence, phonosemantics can potentially become a very important tool in the process of naming.

\section{Conclusions}

The results of the experiment described in this paper confirm the potential of marketing phonosemantics as a tool of influence on the consumer. The experiment, which proved the potential of marketing phonosemantics, was conducted on a massive group of people by means of crowdsourcing. The subconscious auditory perception of fantasy words is connected with different types of associations. The experiment showed that these associations generate diverse factors (both phonetic and non-phonetic), and they do not appear randomly but can be predicted and controlled. Phonetic factors in the process of coining a fantasy word are stronger than non-phonetic ones but both should be taken into account.

The experiment questioned the possibility of putting a deeper sense into a fantasy word and proved the hypothesis about the sounding of a fantasy word as the principal source of information for the customer. Hence, the results of the linguistic experiment can be applied practically to the process of naming in marketing and also in slogans, and advertising texts production. As a matter of fact, the mechanisms of creating the name, slogan, and advertising text can be similar to the mechanisms traditionally used in poetry or folk songs. As poets are able to employ literary devices in order to create a powerful connection with their audience, advertisers can use text, which, besides being 
informational, has aesthetical functions and can be easily recognizable, allowing for the establishment of a perfect formula to attract consumers. In comparison to poetry, for example, an advertising text has much less time to provide the effect needed, so the mechanisms of creating the appropriate name, slogan, and advertising text should be even more powerful. The experiment confirmed that one of such mechanisms can be marketing phonosemantics.

The results of the first stage of the experiment are as follows:

1) the sounding of different fantasy words can cause the same associations in a massive group of people;

2) employing the sound symbolism phenomenon, it is possible to put the specific characteristics of a brand in the sounding of a fantasy name: softness, hardness, liquidity, sharpness, size, etc.;

3) respondents evaluate the name of a brand in the context of the country of origin and make generalizations about the brand according to the sounding of the word denoting it;

4) round-angular symbolism is the most important factor influencing the perception of a fantasy word (in comparison with size symbolism);

5) the associations of the word in isolation, on the one hand, and in relation to any specific goods and services, on the other, can be different (depending on the context of the fantasy word);

6) there are some factors besides the sounding of the word, which are also important in the perception of a fantasy word: the length of the word, speed of articulation, word gender, etc.

Making a suitable combination of all the factors influencing fantasy word perception can not only help create a good brand name but also prevent any misunderstandings about the price, taste, target audience, etc. For example, the sounding of the name of a beauty salon can evoke associations with luxury and expensive costs while in reality the prices can be cheap. This misunderstanding can disappoint both the customer who 
will expect a higher level of the service and the salesman who will not get the customer to purchase his commodity because he/she is not attracted by the name, which is associated with a top service.

In our opinion, the brand name creator should make a list of attributes to describe the product and to define the message he/she intends to get across to the customer. Only after that is it sensible to choose the sounds that can be used in the new name. Of course, the name can be taken from the existing vocabulary but it will not necessarily be effective, memorable, or able to compete with other brands. In addition, the brand name may not even become a registered trade mark because the current lexical pool, which can be used in the process of naming, is limited, and it may appear that the chosen word has already been registered. Nevertheless, a lot of salesmen have to create new names, which can become one of the main factors influencing the customer's choice in the situation of high competitiveness.

The name is the first thing that a customer hears when he/she gets acquainted with the brand, and the first thing the salesman pronounces when presenting himself. Therefore, the mechanisms of naming in marketing are expected to be original and even fanciful. One of these mechanisms is connected with marketing phonosemantics, whose potential is proven by this experiment. However, the experiment on proving the potential of phonosemantic analysis in the process of naming will continue: the more respondents' answers are collected, the more accurate the results will be.

\section{References}

Andreeva, M.V. (2003). Psychological basis of brand creation and its functioning. Thesis for the candidate degree in psychology. Speciality 19.00.05 - social psychology. Moscow: State Management University. / Andreeva M.V. Psikhologicheskiye osnovy obrazovaniya $i$ funktsionirovaniya brenda. Dissertatsiya na soiskaniye uchyonoj stepeni kandidata psikhologicheskikh nauk. Spetsial'nost' 19.00.05 - sotsial'naya psikhologiya. Moskva: Gosudarstvennyj universitet upravleniya. / Андреева М.В. 
Психологические основы образования и функционирования бренда. Специальность 19.00.05 - социальная психология. Диссертация на соискание ученой степени кандидата психологических наук. Москва: Государственный университет управления.

Auracher, J., Albers, S., Zhai, Y. et al. (2011). P is for happiness, $\mathrm{N}$ is for sadness: Universals in sound iconicity to detect emotions in poetry. In Discourse processes, 48 (1), p. 1-25.

Bratchikova, E.A. (2011). Certain theory and methodology aspects of the modern phonosematics researches. In Young scientist, 12, p. 226-229. / Bratchikova E.A. Nekotorye aspekty teorii i metodologii sovremennykh fonosemanticheskikh issledovanij. In Molodoj uchenyj, 12, s. 226-229. / Братчикова Е.А. Некоторые аспекты теории и методологии современных фоносемантических исследований. In Молодой ученый, 12, с. 226-229.

Čibej, J., Fišer, D. \& Kosem, I. (2015). The role of crowdsourcing in lexicography. In Proceedings of the eLex 2015 conference "Electronic lexicography in the $21^{\text {st }}$ century: Linking lexical data in the digital age", Herstmonceux Castle, United Kingdom, August 11-13, p. 70-83.

Coombes, M.D. (2014). Language as a linguistic art: The expression of emotion in the spoken and written world. MA Thesis. Leicester: De Montfort University. Available at: $\quad$ http://www.academia.edu/9664498/Language_as_a_Linguistic_Art__The_Expression_of_Emotion_in_the_Spoken_and_Written_Word

Danilchuk, M.V. (2016). The potential of phonosemantic analysis in the naming process in marketing. In Newsletter of the Herzen State Pedagogical University of Russia, 181, p. 29-35. / Danil'chuk M.V. Potentsial fonosemanticheskogo analiza v protsesse nominatsii $\mathrm{v}$ marketinge. In Izvestiya Rossijskogo gosudarstvennogo pedagogicheskogo universiteta im. A.I. Gertsena, 181, s. 29-35. / Данильчук М.В. Потенциал фоносемантического анализа в процессе номинации в маркетинге. In Известия Российского государственного педагогического университета им. А.И. Гериена, 181, с. 29-35. 
Danilchuk, M.V. (2017). Special aspects of brand names and advertising slogans translation. In Proceedings of the Herzen State Pedagogical University of Russia, 183, p. 107-112. / Danil'chuk M.V. Osobennosti perevoda nazvanij brendov i reklamnykh sloganov. In Izvestiya Rossijskogo gosudarstvennogo pedagogicheskogo universiteta im. A.I. Gertsena, 183, s. 107-112. / Данильчук М.В. Особенности перевода названий брендов и рекламных слоганов. In Известия Российского государственного педагогического университета им. А.И. Гериена, 183, с. 107112.

Dmitrieva, E. (1998). Focus groups in marketing and sociology. / Dmitriyeva E. Fokus gruppy $v$ marketinge $i$ sotsiologii. / Дмитриева Е. Фокус-группь в маркетинге $и$ соииологии. Available at: http://www.e-reading.by/bookreader.php/144428/Fokusgruppy_v_marketinge_i_sociologii.pdf

Howe, J. (2006a). Crowdsourcing: A definition. Available at:

http://crowdsourcing.typepad.com/cs/2006/06/Crowdsourcing_a.html

Howe, J. (2006b). The rise of crowdsourcing. Wired. Available at:

https://www.wired.com/2006/06/crowds/

Ivashneva, S.V. (2014) Possibilities of crowdsourcing use in the system of skills development of teaching staff. In Newsletter of the Northern (Arctic) Federal University. Human and social sciences, 5, p. 157-161. / Ivashneva S.V. Vozmozhnosti ispol'zovaniya kraudsorsinga $\mathrm{v}$ sisteme povysheniya kvalifikatsii pedagogicheskikh rabotnikov. In Vestnik Severnogo (Arkticheskogo) federal'nogo universiteta. Gumanitarnyye i sotsial'nyye nauki, 5, s. 157-161. / Ивашнева С.В. Возможности использования краудсорсинга в системе повышения квалификации педагогических работников. In Вестник Северного (Арктического) федерального университета. Гуманитарные и соџиальные науки, 5, с. 157-161. Kietzmann, J. H. (2016). Crowdsourcing: A revised definition and introduction to new research. In Business horizons, p. 1-3.

Köhler, W. (1929). Gestalt Psychology. New York: Liveright.

Kovic, V., Plunkett, K., \& Westermann, G. (2010). The shape of words in the brain. In Cognition, 114 (1), p. 19-28. DOI: http://dx.doi.org/10.1016/j.cognition.2009.08.016 
Kozhanova, V.Yu. (2007). Linguistic basis of the process of naming of the brands (using the example of English and Russian languages). Synopsis for thesis for the candidate degree in philology. Speciality 10.02.19 - language theory. Krasnodar: South Federal University. / Kozhanova V.Yu. Lingvisticheskiye osnovy naimenovanij brendov (na primere anglijskogo $i$ russkogo yazykov). Avtoreferat dissertatsii na soiskaniye uchenoj stepeni kandidata filologicheskikh nauk. Spetsial'nost' 10.02.19teoriya yazyka. Krasnodar: Yuzhnyj federal'nyj universitet. / Кожанова В.Ю. Лингвистические основы наименований брендов (на примере английского и русского языков). Автореферат диссертации на соискание ученой степени кандидата филологических наук. Специальность 10.02 .19 - теория языка. Краснодар: Южный федеральный университет.

Kulikova, E.V. (2008). Linguistic specificity of the advertising discourse. In Newsletter of Lobachevsky University of Nizhny Novgorod, 4, p. 197-205. / Kulikova E.V. Yazykovaya spetsifika reklamnogo diskursa. In Vestnik Nizhegorodskogo universiteta imeni N.I. Lobachevskogo, 4, s. 197-205. / Куликова Е.В. Языковая специфика рекламного дискурса. In Вестник Нижегородского университета имени Н.И. Лобачевского, 4, с. 197-205.

Kurochkin, A.V. (2013). Crowdsourcing as a new method of political management under the conditions of the network society. In Historical, philosophical, political, and juridical sciences, cultural science and study of art. Questions of theory and practice, 9, p. 78-81. / Kurochkin A.V. Kraudsorsing kak novyj metod politicheskogo upravleniya $\mathrm{v}$ usloviyakh setevogo obschestva. In Istoricheskiye, filosofskiye, politicheskiye i yuridicheskiye nauki, kul'torologiya i iskusstvovedeniye. Voprosy teorii $i$ praktiki, 9, s. 78-81. / Курочкин А.В. Краудсорсинг как новый метод политического управления в условиях сетевого общества. In Исторические, философские, политические и юридические науки, культурология и искусствоведение. Вопросы теории и практики, 9, с. 78-81.

Kutserubov, A.E. (2011). Marketing phonosemantics. In Social and economic phenomana and processes, 10, p. 108-110. / Kutserubov A.E. Marketingovaya fonosemantika. In Sotsial'no-ekonomicheskiye yavleniya i protsessy, 10, s. 108-110. I 
Куцерубов А.Е. Маркетинговая фоносемантика. In Социально-экономические явления и прочессы, 10, с. 108-110.

Magnus, M. (2001). What's in a word? Studies in phonosemantics. PhD dissertation. Trondheim: University of Trondheim. Available at: http://www.trismegistos.com/Dissertation/dissertation.pdf

Nazvanova, I.A. (2013). Special aspects of the modern ergonymy. In Proceedings of Southern Federal University, 10, p. 25-30. / Nazvanova I.A. Osobennosti sovremennoj ergonimii. In Izvestiya Yuzhnogo federal'nogo universiteta, 10, s. 25-30. / Названова И.А. Особенности современной эргонимии. In Известия Южного федерального университета, 10 , с. 25-30.

Osgood, C.E. (1967). The measurement of meaning. Urbana: University of Illinois Press.

Pankrukhin, A.P. (2011). Crowdsourcing - provocative marketing aggressor: Principles, content, technologies. In Practical marketing, 1 (167), p. 3-10. / Pankrukhin A.P. Kraudsorsing - soblaznitel'nyj marketingovyj agressor: Printsipy, soderzhaniye, tekhnologii. In Prakticheskij marketing, 1 (167), s. 3-10. / Панкрухин А.П. Краудсорсинг - соблазнительный маркетинговый агрессор: Принципы, содержание, технологии. In Практический маркетинг, 1 (167), с. 3-10.

Ramachandran, V.S., \& Hubbard, E.M. (2001). Synaesthesia - a window into perception, thought and language. In Journal of consciousness studies, 8 (12), p. 3-34. Remchukova, E.N., Sokolova, T.P. \& Makhiyanova, L.R. (2015). Naming problems: New Russian place names in linguistic and creative aspects. In Human, social, and economic sciences, 9, p. 328-330. / Remchukova E.N., Sokolova T.P. \& Makhiyanova, L.R. Problemy nejminga: Novyye russkiye urbanonimy v lingvokreativnom aspekte. In Gumanitarnyye, sotsial'no-ekonomicheskiye i obschestvennyye nauki, 9, s. 328-330. / Ремчукова Е.Н., Соколова Т.П. \& Махиянова Л.Р. Проблемы нейминга: Новые русские урбанонимы в лингвокреативном аспекте. In Гуманитарные, сочиальноэкономические и общественные науки, 9, с. 328-330. 
Shestakova, I.G. Pragmatic orientation as a text production factor (based on the material of the scientific and technical advertising). / Shestakova I.G. Pragmaticheskaya napravlennost' kak tekstoobrazuyuschij faktor (na materiale nauchno-tekhnicheskoj reklamy). / Шестакова И.Г. Прагматическая направленность как текстообразующий фактор (на материале научнотехнической рекламы). Available at:

http://elib.altstu.ru/elib/books/Files/pa1999_1/pages/13/pap_13.html

Sapir, E. (1929). A study in phonetic symbolism. In Journal of experimental psychology, 12(3), p. 225-239. DOI: http://dx.doi.org/10.1037/h0070931

Shinohara, K., \& Kawahara, S. (2012). A cross-linguistic study of sound symbolism: The images of size. In Proceedings of Berkeley Linguistic Society. Rolle, N., Steffman, J., \& Sylak-Glassman, J. (eds.). Berkeley: The Linguistic Society of America, p. 396410. DOI: http://dx.doi.org/10.3765/bls.v36i1.3926

Skok, D.O. (2011). Problems and importance of naming in the advertising message perception by the different target groups. In Newsletter of MGIMO University, 5, p. 232-234. / Skok D.O. Problemy i rol' nejminga v vospriyatii reklamnykh soobschenij razlichnymi tselevymi gruppami. In Vestnik MGIMO Universiteta, 5, s. 232-234. I Скок Д.О. Проблемы и роль нейминга в восприятии рекламных сообщений различными целевыми группами. In Вестник МГИМО Университета, 5, с. 232234.

Sociology in a new light. / Sotsyologiya ро-поvоти. / Социология по-новому. Available at: http://socioline.ru/rv.php

Stashko, H. (2017). When phonetics matters: Creation and perception of female images in song folklore. In Lege artis. Language yesterday, today, tomorrow. The journal of University of SS Cyril and Methodius in Trnava. Warsaw: De Gruyter Open, II (1), p. 299-335. DOI: 10.1515/lart-2017-0008

Surowiecki, J. (2007). The wisdom of crowds: Why the many are smarter than the few and how collective wisdom shapes business, economics, societies and nations. Moscow: I.D. Vil'yame. / Shurov'yeski Dzh. Mudrost' tolpy. Pochemu vmeste my umneye, chem poodinochke, i kak kollektivnyj razum formiruyet biznes, ekonomiku, 
obschestvo i gosudarstvo. Moskva: I.D. Vil'yame. / Шуровьески Дж. Мудрость толпы. Почему вместе мы умнее, чем поодиночке, и как коллективный разум формирует бизнес, экономику, общество и государство. Москва: И.Д. Вильяме. Ulanovich, O.I. (2013). Suggestive function of the linguistic iconic symbols: The problem of the advertising slogan effects adaptation in the process of translation. In Newsletter of Tomsk State University. Philology, 4 (24), p. 42-51. / Ulanovich O.I. Suggestivnaya funktsiya yazykovykh izobrazitel'nykh simvolov: Problema peredachi effektov vozdejstviya pri perevode reklamnykh sloganov. In Vestnik Tomskogo gosudarstvennogo universiteta. Filologiya, 4 (24), s. 43-51. / Уланович О.И. Суггестивная функция языковых изобразительных символов: Проблема передачи эффектов воздействия при переводе рекламных слоганов. In Вестник Томского государственного университета. Филология, 4 (24), с. 43-51.

Vegener, Yu.S. (2012). Naming in the system of the brand formation and promotion. In Omsk science newsletter, 1 (105), p. 260-262. / Vegener Yu.S. Nejming v sisteme formirovaniya i prodvizheniya brenda. In Omskij nauchnyj vestnik, 1 (105), s. 260-262. / Вегенер Ю.С. Нейминг в системе формирования и продвижения бренда. In Омский научный вестник, 1 (105), с. 260-262.

Volodina, A.N. (2011). Influence of the advertising on the attitude formation of the customer to the brand. In Siberian psychological journal, 42, p. 67-77. / Volodina A.N. Vliyaniye reklamy na formirovaniye otnosheniya potrebitelya k brendu. In Sibirskij psikhologicheskij zhurnal, 42, s. 67-77. / Володина А.Н. Влияние рекламы на формирование отношения потребителя к бренду. In Сибирский психологический журнал, 42, с. 67-77.

Wagner, R. The psychological reality of iconism and its impact on the English language. Available at: https://www.academia.edu/7038443/The

Psychological_Reality_of_Iconism_and_its_Impact_on_the_English_Language

Yagafarova, G.N. (2014). On factors influencing the process of naming in language. In Fundamental research, 12 (11), p. 2505-2508. / Yagafarova G.N. O faktorakh, vliyayuschikh na protsess nominatsii v yazyke. In Fundamental'nye issledovaniya, 12 
(11), s. 2505-2508. / Ягафарова Г.Н. О факторах, влияющих на процесс номинации в языке. In Фундаментальные исследования, 12 (11), с. 2505-2508. Yagodkina, M.V., Ivanova, A.P. \& Slastushinskaya, M.M. (2014). Advertising in the communicative process. Saint Petersburg: Piter. / Yagodkina M.V., Ivanova A.P. \& Slastushinskaya M.M. Reklama v kommunikatsionnom protsesse. Sankt-Peterburg: Piter. / Ягодкина М.В., Иванова А.П. \& Сластушинская М.М. Реклама в коммуникационном процессе. Санкт-Петербург: Питер.

Zhuravlev, A.P. (1974). Phonetic meaning. Leningrad: Leningrad State University. I Zhuravlev A.P. Foneticheskoye znacheniye. Leningrad: Leningradskij Gosudarstvennyj Universitet. / Журавлев А.П. Фонетическое значение. Ленинград: Ленинградский Государственный Университет.

Zhuravlev, A.P. (1991). Sound and sense. Moscow: Prosvescheniye. / Zhuravlev A.P. Zvuk i smysl. Moskva: Prosvescheniye. / Журавлев А.П. Звук и смысл. Москва: Просвещение.

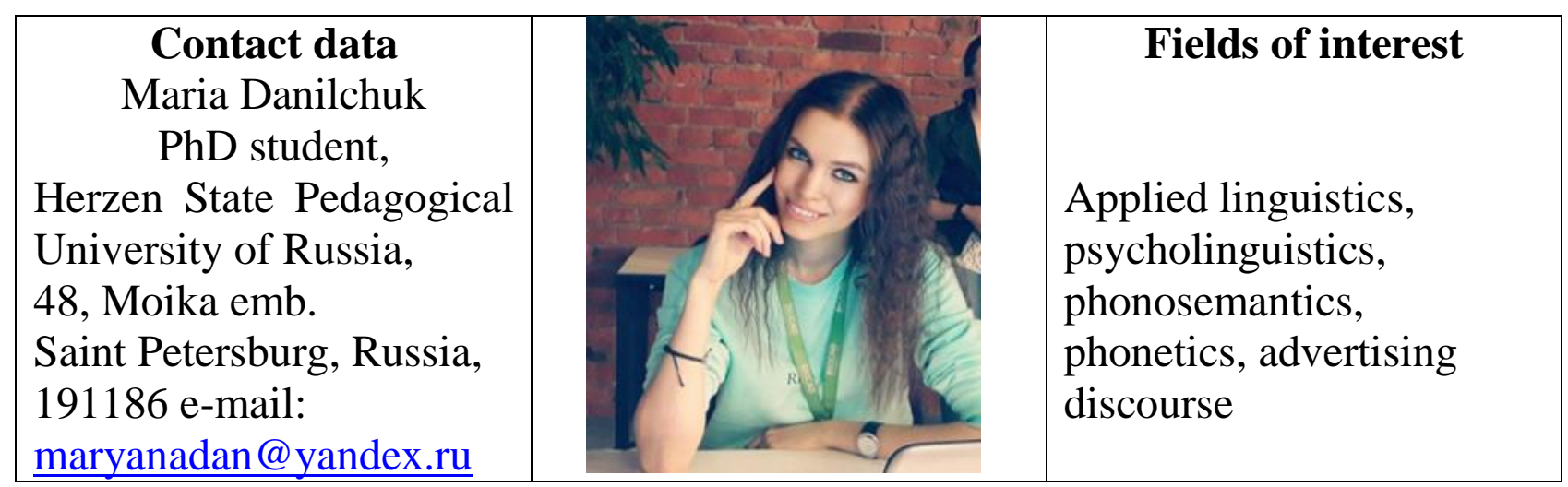

\section{Résumé}

The new term marketing phonosemantics was coined in the $21^{\text {st }}$ century and is defined as an ability of sounds in the brand name to influence the customer with the help of creative and even aggressive methods. A brand name is the first thing that gives information about the product or service. Furthermore, a brand name must be memorable, informative, and impressive in order to be competitive on the market. Previously, it was supposed that the sequence of sounds in fantasy names is of prime importance for the customer. The previous experiments on phonosemantics described 
in academic literature have already confirmed that phonosemantics in isolation "works". The current experiment had to show how phonosemantics functions in relation to brand names. The results of the preliminary experiment involving a group of 30 respondents have showed a wide range of factors that influence the customer during brand name perception: it is not only the sounding of the word itself (associations provided by sound symbolism), but also other phonetic factors, etc. The preliminary experiment helped correct and improve the questionnaire in order to enhance the validity of the experiment on a massive group of people by means of crowdsourcing. The paper represents the preliminary results of the experiment (with the involvement of 300 respondents), which confirmed the potential of phonosemantic analysis in the process of naming. Thus, as a consequence of the sound symbolism phenomenon described in this paper, it is possible to include the specific characteristics of a brand in the sounding of the word: softness, hardness, liquidity, sharpness, size, etc. The results of this linguistic experiment can be useful in real life and can make marketing phonosemantics an important tool of influence on the customer's mind.

Key words: phonosemantics, marketing phonosemantics, naming, brand name, experimental phonosemantics, neologism.

Article was received by the editorial board 04.06.18;

Reviewed 17.08.18. and 21.08.18.

Similarity Index $0 \%$ 